\title{
\#USES
}

\section{Assessment of Environmental Flows in the Middle Verde River Watershed, Arizona}

This report summarizes
analyses of middle Verde
River watershed environ-
mental flows detailed in U.S.
Geological Survey Scientific
Investigations Report 2017-
5100, "Preliminary synthesis
and assessment of environ-
mental flows in the middle
Verde River watershed, Ari-
zona, by N.V. Paretti, A.M.D.
Brasher, S.L. Pearlstein, D.M.
Skow, B. Gungle, and B.D.
Garner. All figures from Paretti
and others (2018) unless other-
wise noted.
EXPLANATION
$\triangle$ USGS streamgage location
09503700:Verde River near Paulden, AZ 0904000: Verde River near Clarkdale, AZ 09504420: Oak Creek near Sedona, AZ 09504500:Oak Creek near Cornville, AZ 09505800: West Clear Creek near Camp Verde, AZ
Pilot study fish and aquatic insect locations - Pilot study aquatic insect locations
A Pilot study fish locations

\section{Introduction}

The Verde River is among the largest streams in Arizona. Its watershed covers 4.2 million acres in central Arizona, includes about 500 miles of perennial streams, and provides 40 percent of the

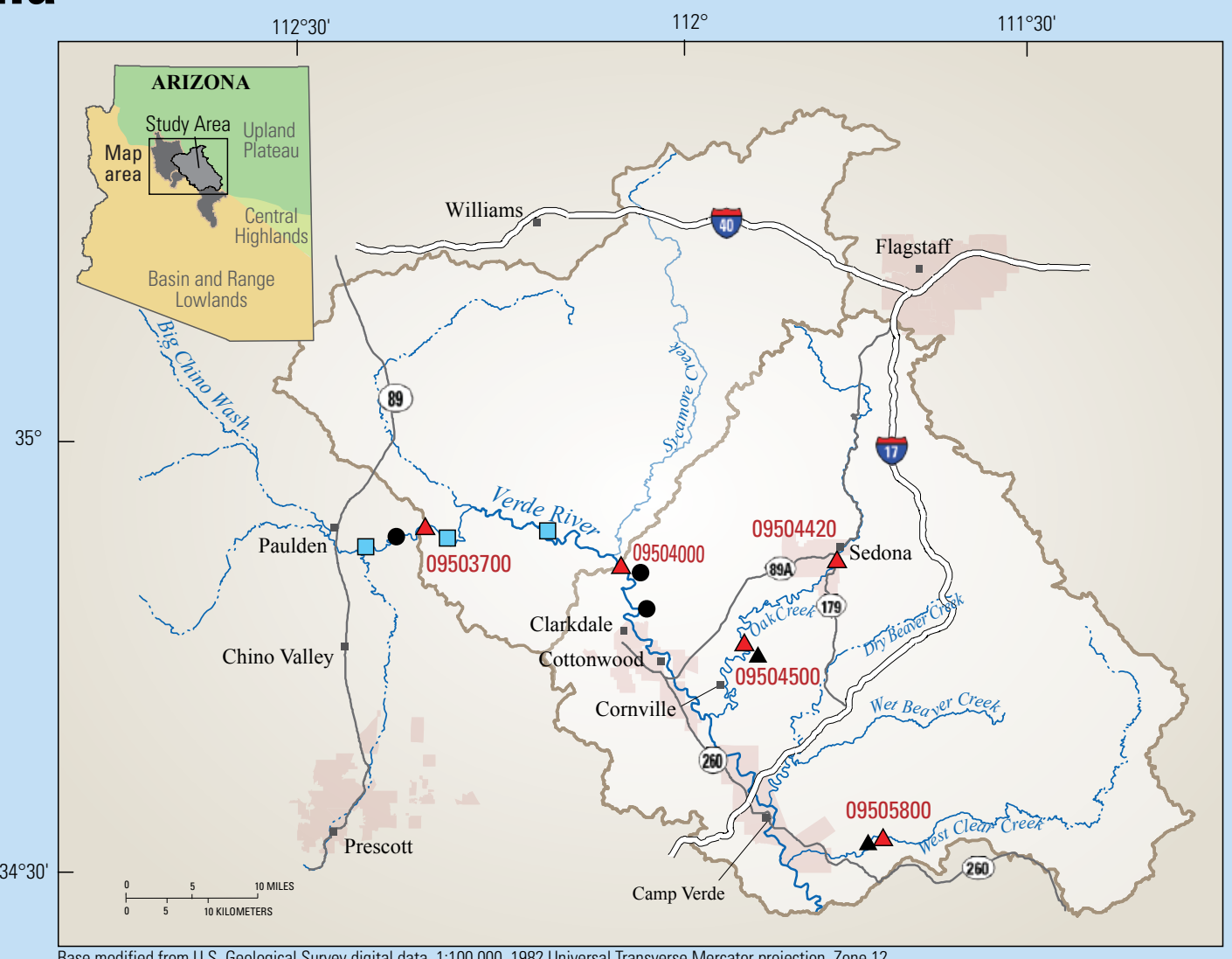

Middle Verde River watershed, Arizona, including streamgaging stations, major towns, and tributaries. Map modified from Garner and others (2013).

surface water delivered to the Phoenix metropolitan area by the Salt River Project (The Nature Conservancy, 2009). The Verde River watershed is home to a number of native fish and special status species.
The flows that occur in the middle Verde River watershed are largely unregulated and are less affected by urban use, urban and agricultural runoff, and channelization than in the lower Verde River watershed.
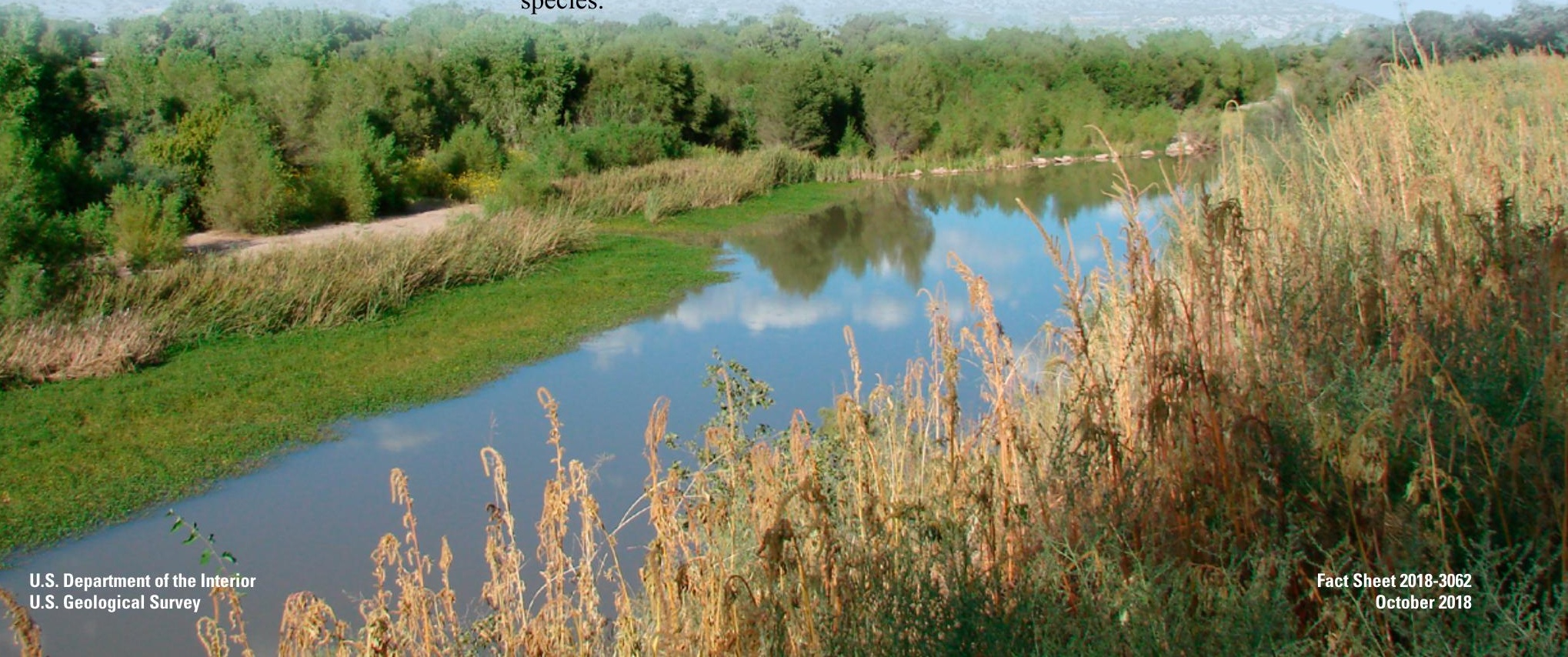
The magnitude, frequency, duration, timing, and rate of change of hydrologic conditions can be used to characterize the entire range of stream flows, from low flows to floods, that are critical to the integrity of river ecosystems (Poff and others, 1997). Environmental flows describe the hydrologic conditions necessary to sustain properly functioning aquatic ecosystems which in turn support human livelihoods and well-being (Arthington and others, 2018). Streams altered by human modifications, such as dams, diversions, or channel engineering, can still be managed to mimic an environmental flow regime that meets ecological and social objectives (Acreman and others, 2014). To understand the consequences of various water-use scenarios to Arizona's middle Verde River watershed ecosystem, the U.S. Geological Survey set out to first understand the system's environmental flows. The purpose of Paretti and others (2018) was to compile existing hydrological and ecological data to better understand environmental flows in the setting of the middle Verde River watershed.

Ecosystem water needs include use by riparian vegetation and the habitat requirements of fish and macroinvertebrates (aquatic insects). The hydrologic characteristics that affect ecosystem water needs include both streamflow (that is, the magnitude, frequency, timing, and variability of flow) and groundwater conditions such as depth to groundwater and annual fluctuations of groundwater levels (Poff and others, 2010; Konrad and others, 2008).

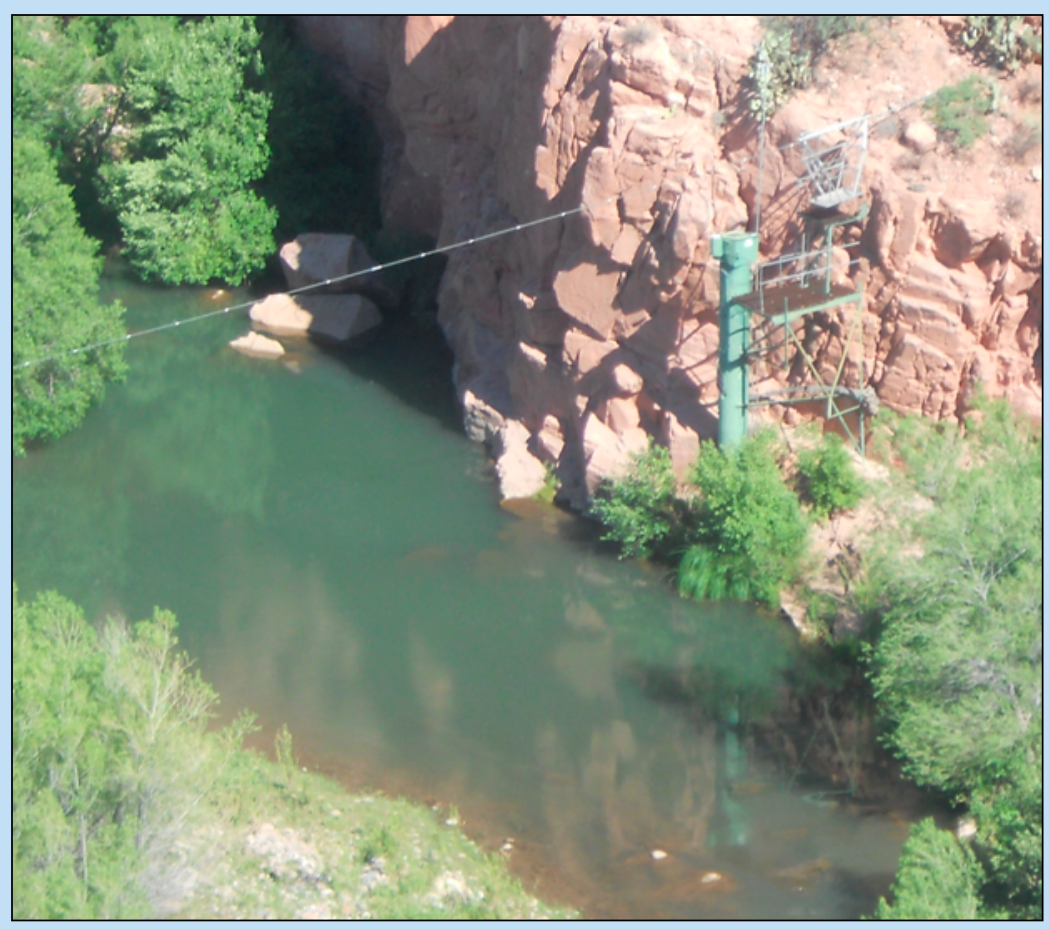

The Verde River north of Clarkdale, Arizona. River flow is toward the viewer. U.S. Geological Survey streamgage 09504000 stilling well and cable way are located on the bank. Photograph by A.M.D. Brasher, U.S. Geological Survey.

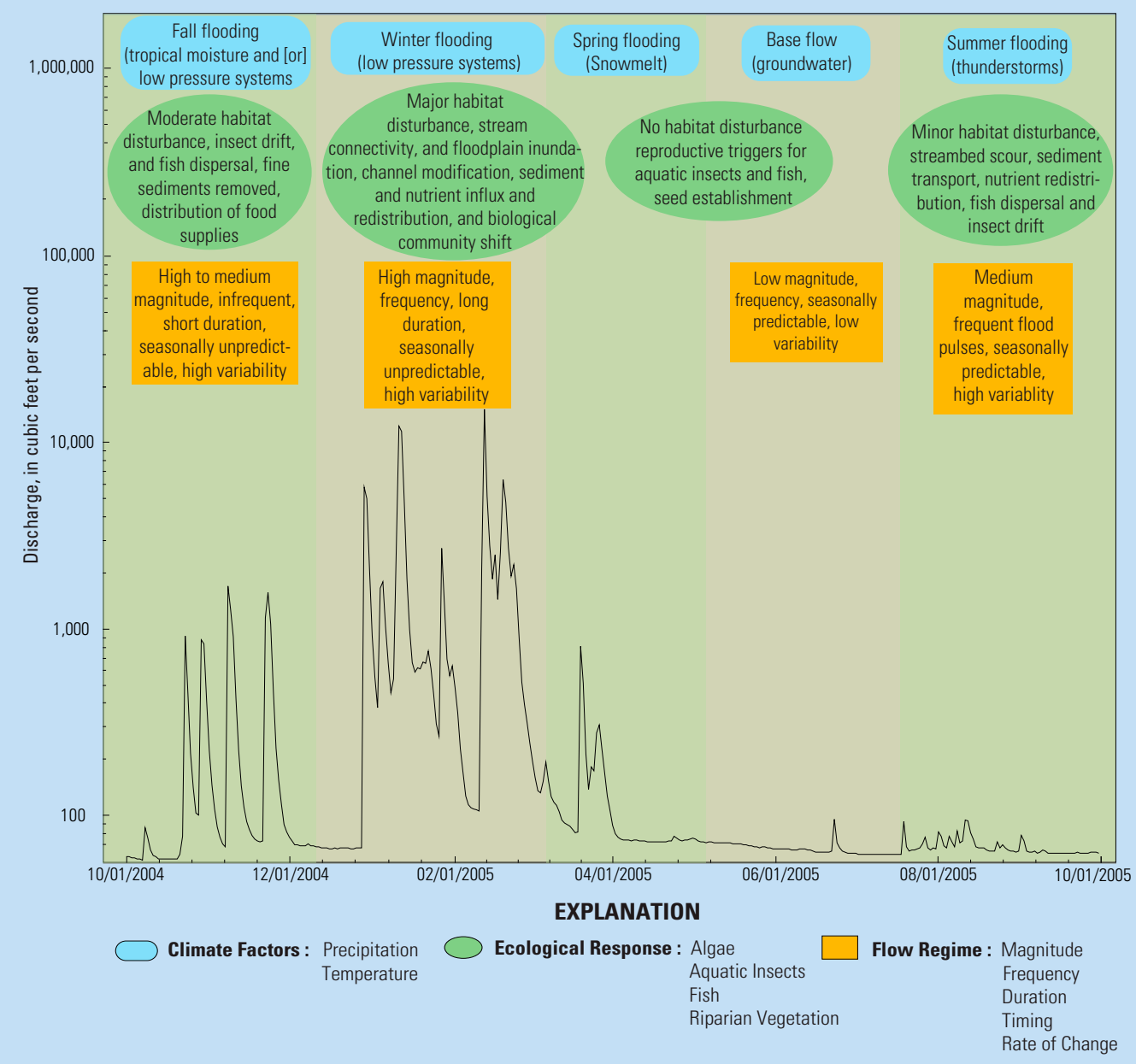

\section{Surface Water and Groundwater}

The first step in determining Verde River environmental flows was to develop estimates of flow regimes that sustain properly functioning ecosystems. The natural hydrologic regime of a river or stream can be divided into four componentsfloods, high-flow pulses, base flows, and extreme low flows. To represent these components of the natural flow regime, measures of magnitude, timing, duration, frequency, and rate of change of streamflow must be developed (Poff and others, 1997).

Southwestern desert streams, including the Verde River, are characterized by large variations in flow magnitude. However, flow in the Verde River and its tributaries is frequently composed entirely of groundwater discharging to the stream channel. Such base-flow regimes are highly dependent on groundwater/ surface-water interactions.

Hydrograph for U.S. Geological Survey stream gage Verde River near Clarkdale, AZ (09504000), water year 2005, demonstrating flow-regime components. AZ, Arizona. Modified from Poff and others (1997) and Bunn and Arthington (2002). 


\section{Riparian Vegetation}

The Verde River watershed contains some of the most extensive acreage of Fremont cottonwood-Goodding willow forest and mixed broadleaf riparian forest in Arizona and is home to the threatened yellow-billed cuckoo and the endangered southwestern willow flycatcher (Stevens and others, 2008). Because of the relatively unregulated flow of the Verde River, riparian vegetation along the banks varies in age, which is instrumental in maintaining forest resiliency.

\section{Aquatic Insects}

Aquatic insects such as mayflies and caddisflies play a crucial role in the food web of a stream ecosystem, and their abundance and diversity is an indicator of stream health. Because these insects live for a year or more and rarely move beyond a given river reach, their response to local waterquality conditions is useful in assessing the ecological condition of a stream. Several aquatic insect community metrics significantly increased or decreased based on flow conditions defined by season, magnitude of flow, presence of river diversions, and stream size (Verde River or tributary).

Aquatic insect samples and habitat measurements were collected from six sites in the upper-middle Verde River to better understand flow-habitat relations. The largest insect diversity was at the Clarkdale streamgage site. The Verde River below Granite Creek site had slower stream velocity, smaller substrate, and greater riparian cover than the other five sites. It also had a different insect community than the other sites, including the greatest variety of caddisfly types, lowest variety of mayfly types, and lowest overall diversity of all locations. Several insect types were observed at the Verde River Below Granite Creek site that were not found at any of the other five locations, likely because of the differences in flow and habitat type. The Paulden streamgage site had the greatest range of stream velocities of all the sites and a large variety of mayfly types, but very low midge diversity. The other four stations were similar in overall diversity and caddisfly types, and in particular, the Perkinsville Bridge and Reitz Ranch samples had similar insect community structures.
An analysis of aerial imagery showed that the upper-middle Verde River watershed has more upland plant species, such as junipers, and fewer lowland species, such as cottonwoods and mesquites, compared to their abundance in the lower-middle sections. Differences in vegetation within the upper-middle and lower-middle reaches appear to be related more to differences in climate and hydrology than to human alterations.
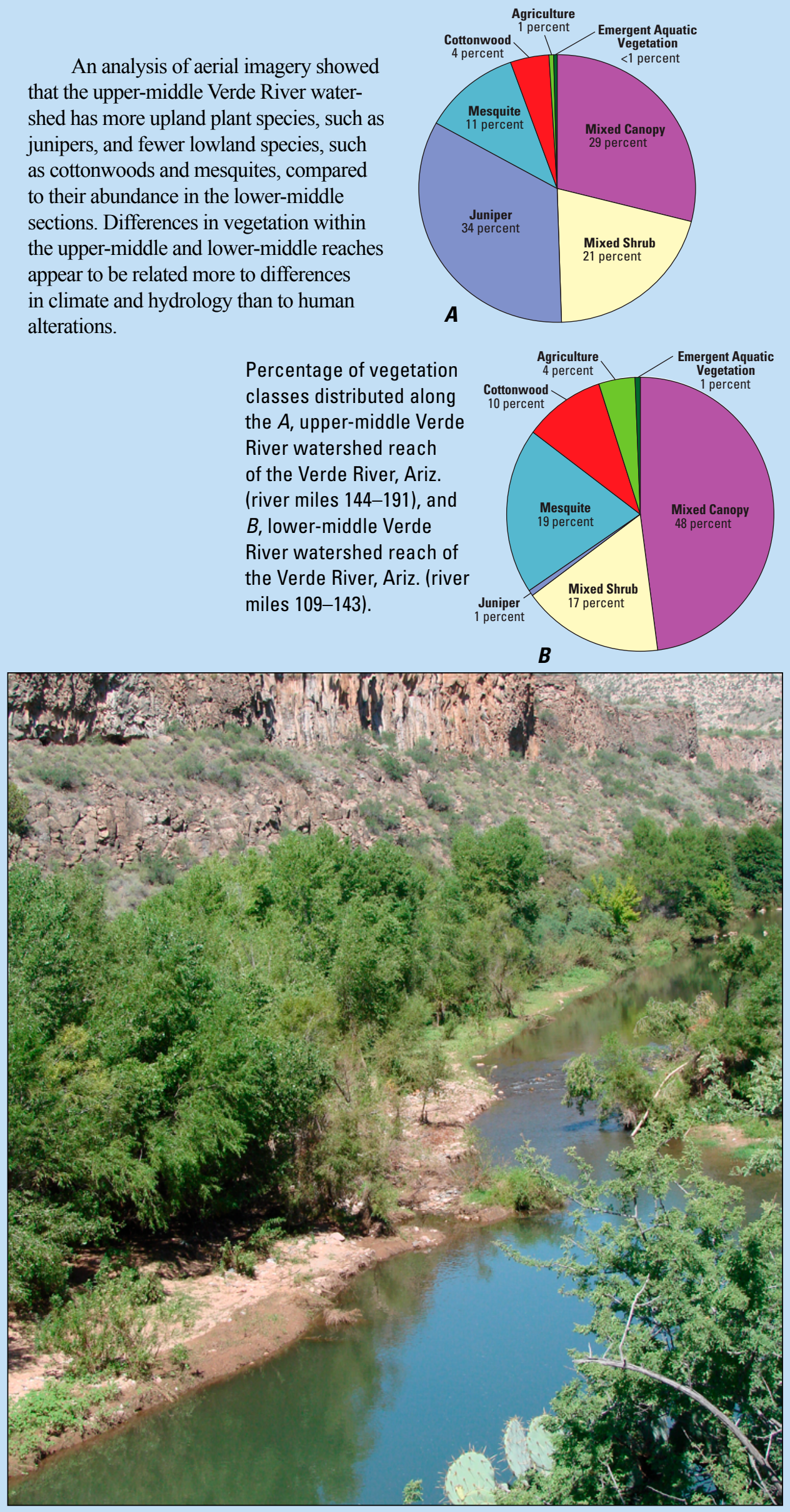

View looking northwest of the Verde River north of Reitz Ranch, Arizona. River flow is toward the viewer. Photograph by N.V. Paretti, U.S. Geological Survey. 
Fish

The native fish of the Southwest are highly adapted to a range of conditions that include extreme temperatures, unpredictable flood flows, and sedimentladen waters (Rinne, 1992; Lytle and Poff, 2004); they are also under stress from changes in river ecosystems and flows. During high flow years, native fish species typically increase in numbers and nonnative species decrease in numbers (Rinne, 2005; Gido and Propst, 2012). In the middle Verde River watershed, native fish have been declining since the introduction of nonnative fish species nearly a century ago; high flows are one of the last remaining natural defenses native fish have against nonnative fish pressures.

The abundance and distribution of native and nonnative fish were determined at five sites in the middle Verde River watershed. Five species were identified as native and 10 were nonnative. Longfin and speckled dace were only collected at the Perkinsville site, and rock bass, black bullhead, and common carp were only collected at Oak Creek. The percentage of non-native species was greater at the Paulden location and at the Oak Creek and West Clear Creek tributaries. The Verde River Below Granite Creek and the Perkinsville sites had similar percentages of individual native fish, but the Verde River Below Granite Creek and the Paulden sites had the most similar fish assemblages.

The median stream velocity associated with the native fish species was significantly faster than that associated with nonnative fish species and native fish used a wider range of velocities than did nonnative species. The median stream velocity associated with the nonnative fish was significantly slower than that of the available microhabitat, and velocities associated with native fish were faster than the median velocity of the available microhabitat. Although both native and nonnative fish used most water depths, nonnative species preferred the shallowest depths whereas native species more commonly used depths greater than 2.3 feet. Both native and nonnative species used all sizes of substrate, but in general, native fish were significantly more likely to use coarser substrates (in particular, gravels and cobbles) than nonnative fish, and nonnative fish preferred smaller diameter substrate than native fish.
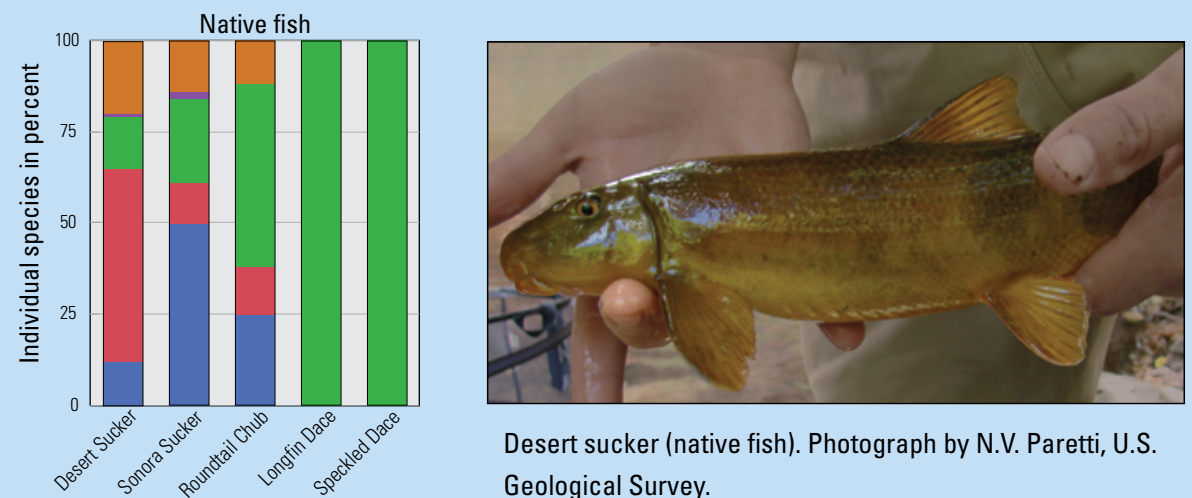

Desert sucker (native fish). Photograph by N.V. Paretti, U.S. Geological Survey.
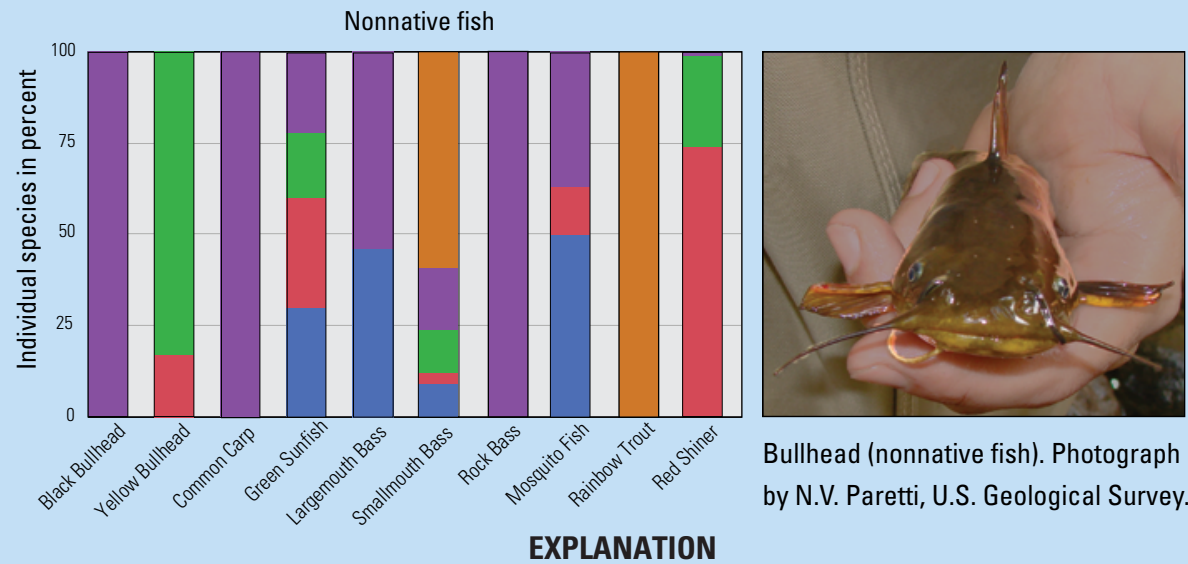

Bullhead (nonnative fish). Photograph by N.V. Paretti, U.S. Geological Survey.

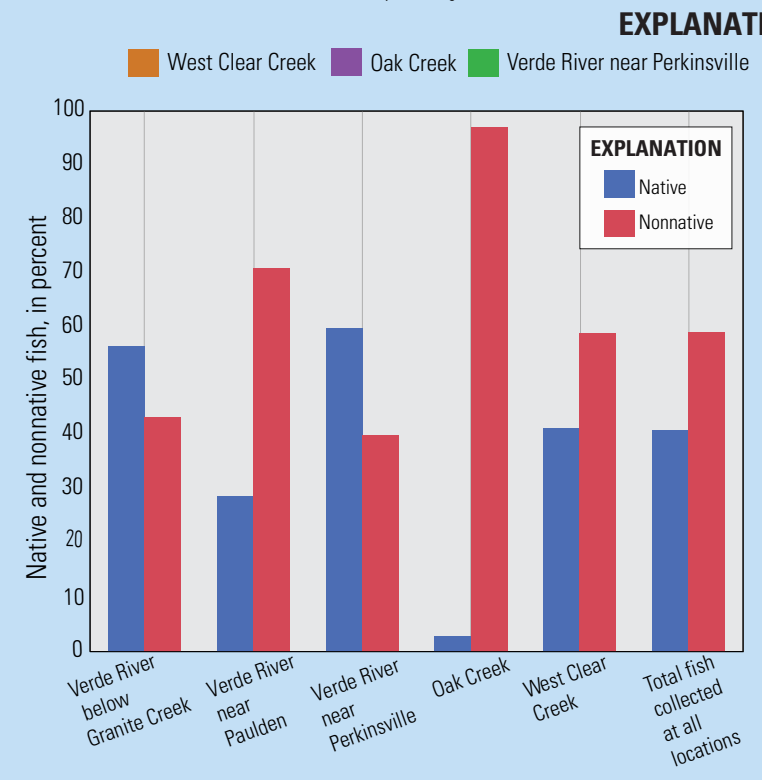

Percentage of native and nonnative fish by location in the middle Verde River watershed, Arizona.

\section{Future Directions}

The empirical relations determined in this study can be used to develop the basis for a conceptual model of environmental flows in the middle Verde River watershed. A robust conceptual model can provide the foundation for developing physically based, quantitative and predictive models of environmental flows for the middle Verde River.

Such models can improve the understanding of the effects of increased stresses from climate varisupply of the Verde River. ability and the demands on the water

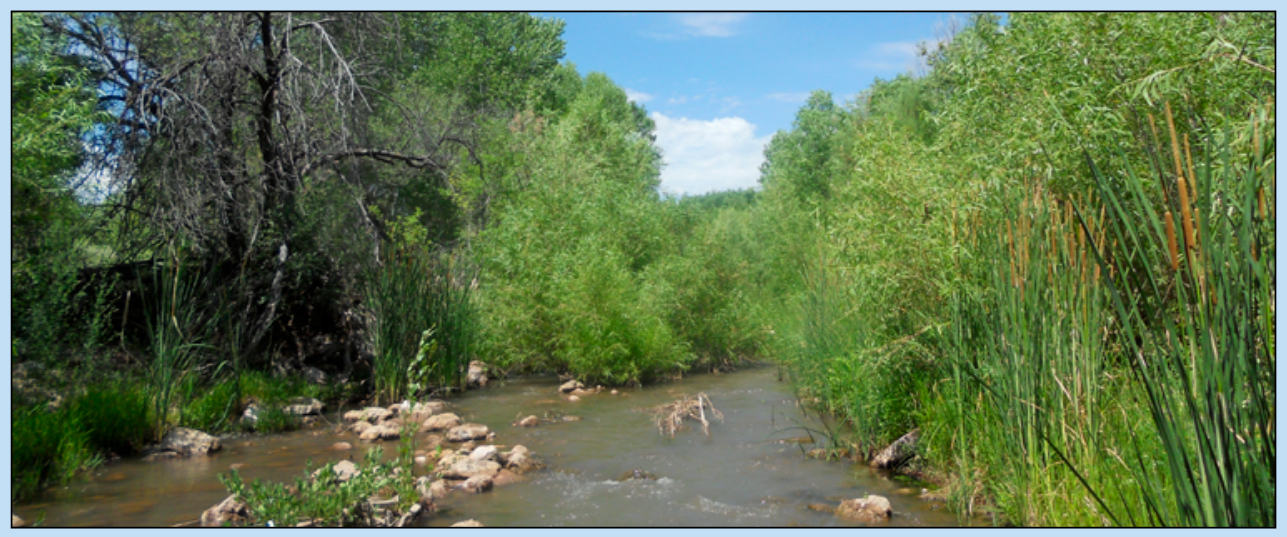

West of the Verde River near Perkinsville, Arizona. River flow is toward the viewer. Photograph by A.M.D.

Brasher, U.S. Geological Survey. 


\section{References Cited}

Acreman, M., Arthington, A.H., Colloff, M.J., Couch, C., Crossman, N.D., Dyer, F., Overton, I., Pollino, C.A., Stewardson, M.J., and Young, W., 2014, Environmental flows for natural, hybrid, and novel riverine ecosystems in a changing world: Frontiers in Ecology and the Environment, v. 12, no. 8, p. 466-473.

Arthington, A.H., Bhaduri, A., Bunn, S.E., Jackson, S.E., Tharme, R.E., Tickner, D., Young, B., Acreman, M., Baker, N., Capon, S. Horne, A.C., Kendy, E., McClain, M.E., Poff, N.L, Richter, B.D., and Ward, S., 2018, The Brisbane Declaration and Global Action Agenda on Environmental Flows (2018): Frontiers in Environmental Science, Policy and Practice Reviews, appendix 1, v. 6, no. 45, p. $1-15$.

Bunn, S.E., and Arthington, A.H., 2002, Basic principles and ecological consequences of altered flow regimes for aquatic biodiviersity: Environmental Management, v. 30, no. 4, p. 492-507.

Garner, B.D., Pool, D.R., Tillman, F.D., and Forbes, B.T., 2013, Human effects on the hydrologic system of the Verde Valley, central Arizona, 1910-2005 and 2005-2110, using a regional groundwater flow model: U.S. Geological Survey Scientific Investigations Report 2013-5029, 47 p.

Gido, K.B., and Propst, D.L., 2012, Long-term dynamics of native and nonnative fishes in the San Juan River, New Mexico and Utah, under a partially managed flow regime: Transactions of the American Fisheries Society, v. 141, no. 3, p. 645-659.

Konrad, C.P., Black, B., Voss, F., and Neale, C., 2008, Integrating remotely acquired and field data to assess effects of setback levees on riparian and aquatic habitats in glacial-melt water rivers: River Research and Application, v. 24, p. 355-372.

By Bruce Gungle and Nicholas V. Paretti

Edited by Katherine Jacques

Layout by Kimber Petersen
Lytle, D.A., and Poff, N.L., 2004, Adaptation to natural flow regimes: Trends in Ecology and Evolution, v. 190, p. 1-7.

Paretti, N.V., Brasher, A.M.D., Pearlstein, S.L., Skow, D.M., Gungle, B., and Garner, B.D., 2018, Preliminary synthesis and assessment of environmental flows in the middle Verde River watershed, Arizona: U.S. Geological Survey Scientific Investigations Report 2017-5100, 104 p., accessed July 2018, at https://doi.org/10.3133/sir20175100.

Poff, N.L., Allan, J.D., Bain, M.B., Karr, J.R., Prestegaard, K.L., Richter, B.D., Sparks, R.E., and Stromberg, J.C., 1997, The natural flow regime: Bioscience, v. 47, no. 11, p. 769-784.

Poff, N.L., Richter, B.D., Arthington, A.H., Bunn, S.E., Naiman, R.J., Kendy, E., Acreman, M., Apse, C., Bledsoe, B.P., Freeman, M.C., Henriksen, J., Jacobson, R.B., Kennen, J.G., Merritt, D.M. O'Keeffe, J.H., Olden, J.D., Rogers, K., Tharme, R.E., and Warner, A., 2010, The ecological limits of hydrologic alteration (ELOHA)A new framework for developing regional environmental flow standards: Freshwater Biology, v. 55, no. 1, p. 147-170.

Rinne, J.N., 1992, Physical habitat utilization of fish in a Sonoran Desert stream, Arizona, southwest United States: Ecology of Freshwater Fish, v. 1, p. 35-41.

Rinne, J.N., 2005, Changes in fish assemblages, Verde River, Arizona, 1974-2003: American Fisheries Society Symposium, v. 45, p. $115-126$.

Stevens, L.E., Turner, D.S., and Supplee, V., 2008, Wildlife and flow relationships in the Verde River watershed, chap. 5 of Ecological implications of Verde River flows: Arizona Water Institute, The Nature Conservancy, and the Verde River Basin Partnership, p. 51-70.

The Nature Conservancy, 2009, Verde River watershed conservation plan: Tucson, Ariz., The Nature Conservancy, $50 \mathrm{p}$

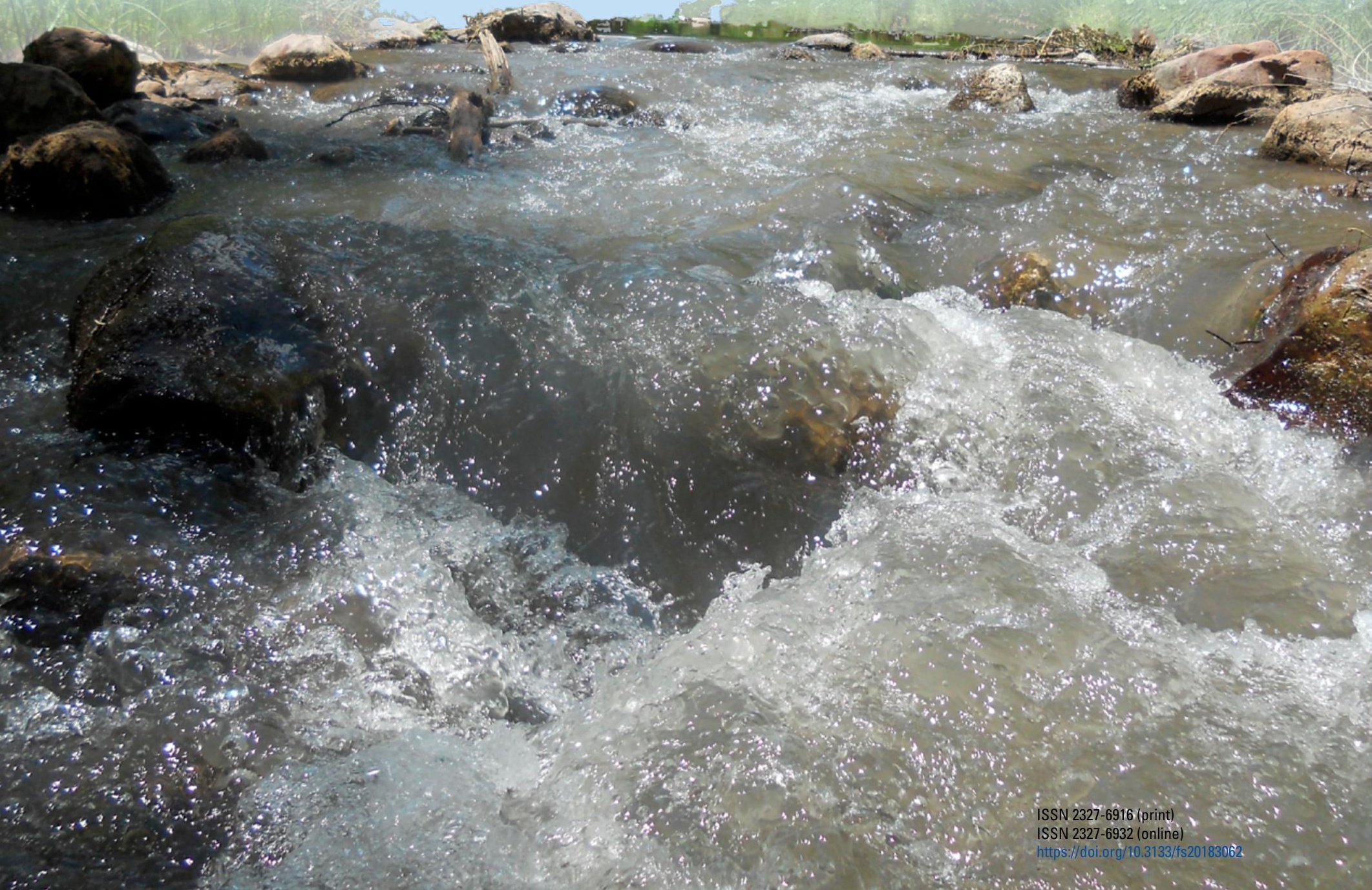

